\title{
ARTÍCULOS
}

\section{LA RETÓRICA DE LA FACTICIDAD EN TIEMPOS DE HIBRIDACIÓN Recreación, Memoria y Realidad en los Docudramas y Documentales Animados}

\author{
Patricia Serrano Abarca \\ Docente investigadora de UCAL \\ ORCID: https://orcid.org/0000-0003-4514-9071
}

\section{RESUMEN}

El artículo analiza los elementos mediante los cuales el discurso fáctico de lo "real" sobrevive en formas de expresión del documental, caracterizadas por la hibridación de géneros y lenguajes. Toma como referencia el docudrama y el documental animado, de uso frecuente en la actualidad, para, a partir de una investigación bibliográfica y del análisis de casos, profundizar en estas dos modalidades de representación, que incorporan la ficción y el arte, recreando una nueva "retórica de la facticidad" en el seno de la hibridación.

Palabras claves: retórica, facticidad, autenticidad, veracidad, argumentación, realidad, narrativa, documental, no ficción, hibridación, docudrama, recreación, reconstrucción, dramatización, documental animado, animación, dibujo, arte, memoria, recuerdo, testimonio.

\section{INTRODUCCIÓN}

Sea pues la retórica la facultad de considerar en cada caso lo que puede ser convincente.

(Aristóteles, trad. en 1998, p. 52).

La retórica de la facticidad es la esencia del discurso de no ficción. Es la manera como el documental, a lo largo de su evolución, intentó alejarse de la ficción para encontrar su identidad como género de representación y, por tanto, como relato de "lo real"; de ese "(...) mundo en el que vivimos en vez de mundos en los que nos imaginamos vivir." (Nichols, 2011, p. 155).

Desde la postura semiótica, autores como Tuchman (1983), Cebrián Herreros (2007) y Nichols (2011) se refieren a la facticidad o autenticidad, como un principio que resalta la relación estrecha entre los referentes reales y su representación, a través de una lógica argumentativa basada en el uso de elementos que son parte de la realidad y que se ofrecen como evidencias de una verdad construida. Según Carl Plantinga (2007), el documental adquiere este carácter de "veracidad expresa", entre otros, gracias al potencial fáctico del registro audiovisual y el poder de similitud de las imágenes que se ofrecen como pruebas de lo real.
Hoy, sin embargo, muchas de las formas de "documentar" una realidad vienen borrando las fronteras con la ficción y el arte, expandiendo la representación a otros lenguajes, más allá del registro audiovisual directo de los acontecimientos, que marcó durante años la esencia retórica de la no ficción.

Sin perder su discurso fáctico y de la mano de la investigación como fuente de conocimiento, el documental ha aprovechado todo el potencial de las narrativas digitales, para la experimentación intertextual, usando la capacidad de recreación que ofrecen otros géneros, como la ficción, y otros lenguajes, como la animación. A sus formas tradicionales, se vienen sumando ( $y$ en algunos casos reviviendo) otras modalidades en las que la retórica de la facticidad cobra aún más importancia, en medio de una panorama donde se mezclan representación y simulación, no ficción y ficción, información y entretenimiento.

\section{PUESTA EN ESCENA DE LA REALIDAD. LA "VOZ" DEL DISCURSO FÁCTICO EN EL DOCUDRAMA.}

(...) É um jogo lúdico, onde as personagens «saem» brevemente da história ficcionalizada e pedem ajuda às pessoas reais para recordar ou esclarecer decisões tomadas em sua vida real. (Fuenzalida, 2008, p. 163).

Valerio Fuenzalida se refiere al uso de entrevistas en los docudramas como la herramienta que establece una ruptura con el relato ficcional de la realidad. Un "juego lúdico" donde los personajes "se salen" brevemente de la historia representada por actores; para "recordar o esclarecer decisiones tomadas en su vida real". Así la voz de aquellas personas que son parte de la realidad dota de veracidad a la escena recreada, convirtiendo a la ficción en un documental dramatizado.

El docudrama, abordado en este artículo como un relato documental que utiliza la técnicas de ficción para la recreación dramática de realidades, tiene sus raíces en la temprana evolución del documental cinematográfico, sus antecedentes radiales y su lucha por recuperar espacios frente al éxito comercial de la ficción.

The March of Time (La Marcha del Tiempo, 1935) es considerado uno de los primeros ejercicios informativos de dramatización 
de la realidad (Barnouw, 1996 y Raventós, Torregrosa y Cuevas, 2012). Basado en un programa radial del mismo nombre, financiado por la revista Time, esta propuesta seriada planteó muchas de las bases de los actuales docudramas.

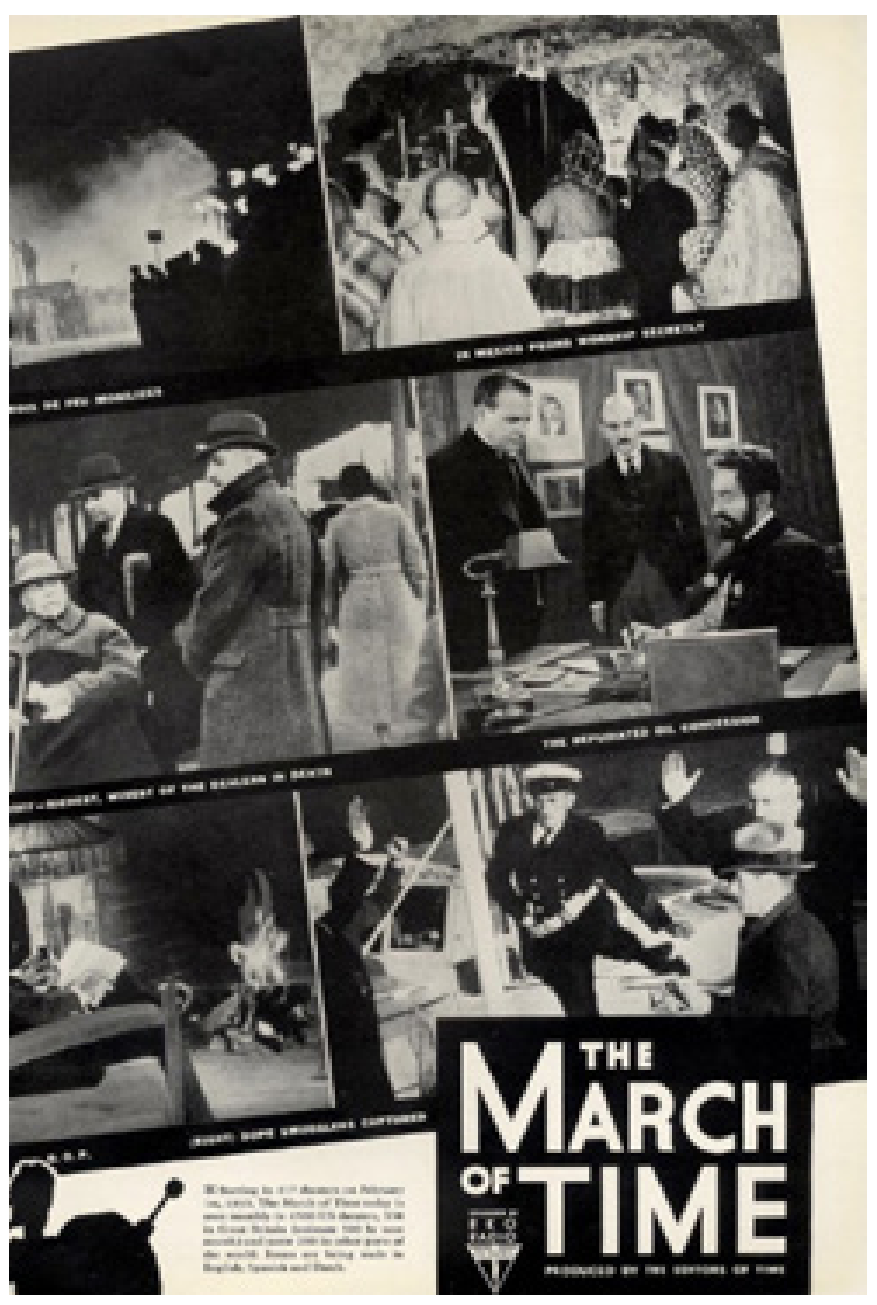

$\triangle$

Tha March of Time (1935). En Citizen Kane \& News On The March Of The Time. El Tiempo y Lo Eterno. (Entrada de blog). Recuperado de https://eltiempoyloeterno.wordpress. com/2017/05/06/eqo-citizen-kane-news-on-the-march-ofthe-time/

La investigación a profundidad, sello del "time style", era la materia prima de guiones dirigidos a la reconstrucción dramática de sucesos, sin posibilidad de ser registrados, que fueron narrados a través de técnicas propias de la ficción. El uso de actores, diálogos, escenografías, vestuarios, etcétera, eran acompañados de la solitaria argumentación de un conductor narrador, erigido como el único símbolo de veracidad.

Antes de este docudrama informativo, empero, ya muchos de los realizadores más importantes de la historia del documental habían usado la dramatización. Dziga Vertov, creador de la escuela de Cine 0jo, compuso algunas escenas ficcionadas para construir un discurso crítico en torno al cine de ficción en "Man with a Movie Camera" (El Hombre de la Cámara, 1929).
Jean Vigo hizo lo propio con toques sarcásticos en "À propos de Nice" (A Propósito de Niza, 1930). Incluso Robert Flaherty, "el padre del documental," usó actores no profesionales en Elephant Boy (Sabú ,1937), argumentando que las verdaderas estrellas de su film no eran los actores, sino la jungla, los

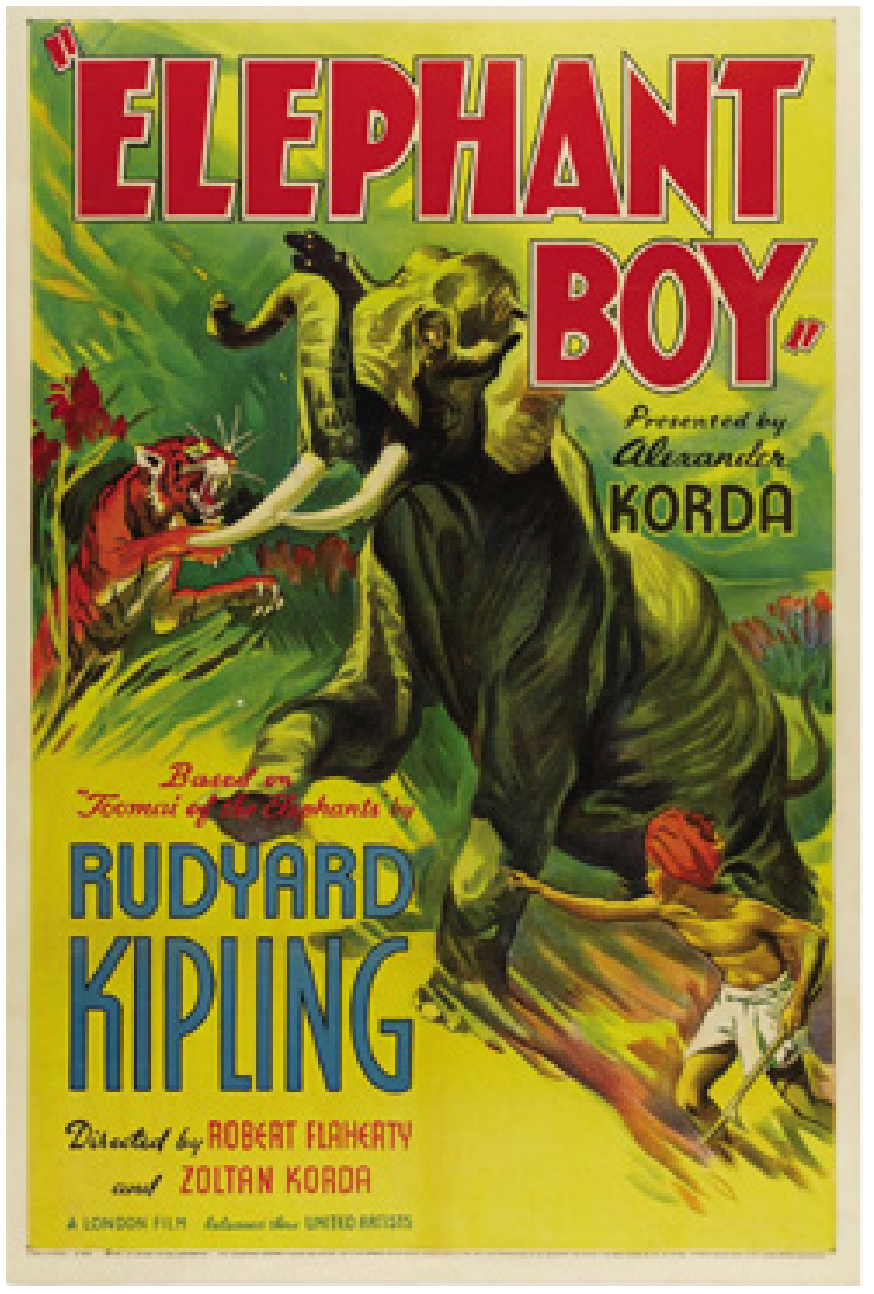

$\triangle$

Elephant Boy (1937). Heritage Auctions, HA.com Recuperado de https://www.ha.com/ https://movieposters.ha.com/itm/ movie-posters/adventure/elephant-boy-united-artists-1937one-sheet-27-x-41-in-the-1940s-and-1950s-sabu-was-oneof-the-most-prosperous-acto-total-/a/633-28237.s

elefantes y el niño; elementos que, según él, le dieron valor documental a la trama. (Flaherty, 1985).

Con el tiempo y el desarrollo de nuevas modalidades de representación, como el Cinema Verité y las formas de reflexión que rompieron con los códigos tradicionales de objetividad, se incluyeron otras voces con mayores grados de veracidad. Los testimonios de protagonistas o testigos de los hechos, así como de especialistas o estudiosos, empezaron a darle autenticidad a los relatos de no ficción y verosimilitud a las dramatizaciones, en un esquema narrativo propio de los documentales participativos.

Destaca entre los documentales dramatizados, The Thin Blue 
Line (La Delgada Línea Azul, 1988) de Errol Morris, que fundó las bases del género policial de no ficción. Este documental examina el asesinato de un policía en Dallas en 1976 y, sobretodo, la condena de Randall Adams, sentenciado como el asesino, después de un proceso legal plagado de errores e incoherencias.

A través de recreaciones basadas en una investigación de rigor y de la inclusión de diferentes puntos de vista representados por las declaraciones de los principales involucrados en este suceso, Morris ofrece un relato que defiende como documental, más allá del uso de la dramatización. “(...) Es un documental. Las entrevistas son con personas reales: el verdadero asesino, el verdadero hombre caído, los verdaderos policías. Y lo que dicen es extemporáneo. No está escrito. Este es el elemento documental, (...)" (Errol Morris en entrevista de Nick Poppy, 2004, trad.)

"La Delgada Línea Azul" mostró, también, un peculiar uso del audiovisual. A través de planos cerrados que recrean acciones, sin identificar a las personas que las realizan; detalles de objetos vinculados con los acontecimientos y efectos sonoros característicos, que llevan la mayor carga simbólica; y el uso de imágenes referenciales de los espacios reales, se conformó un lenguaje que influyó notablemente en el tratamiento de los docudramas policiales posteriores.

A nivel discursivo, aunque Morris usó el ordenamiento clásico de los documentales participativos, intercalando secuencias audiovisuales con la realidad de las declaraciones de los personajes involucrados, rompió con la normas del Cinema Verité al difuminar "la delgada línea" entre ficción y no ficción e incorporar elementos que hasta ese momento eran parte de las Ilamadas "películas de espectáculo". La Delgada Línea Azul es un documental donde no sólo se recrean y simbolizan los hechos, sino también un relato de género que utiliza elementos dramatúrgicos, dosificando la información, sorprendiendo y creando un suspenso propio de las películas policiales de ficción.

A partir de ahí, y hasta el día de hoy, muchos directores vienen repitiendo está fórmula para narrar eventos policiales a través del documental, otorgando diferentes funciones a la ficción y a la representación de la realidad. La dramatización involucra, por un lado, la composición dramatúrgica y la reconstrucción audiovisual de los hechos ocurridos. La representación, por otro, lleva la mayor carga argumentativa y fáctica de la historia, a partir del relato de los protagonistas y testigos de los sucesos, de la información contada a través de intertítulos o de la palabra del narrador, de los espacios reales donde ocurrieron, así como del uso de imágenes de archivo noticioso, policial, judicial 0 casero.

La programación seriada de la televisión tradicional a explotado este género, sin mucho arte, en programas como Unsolved Mysteries (Misterios sin Resolver, 1987) y en canales

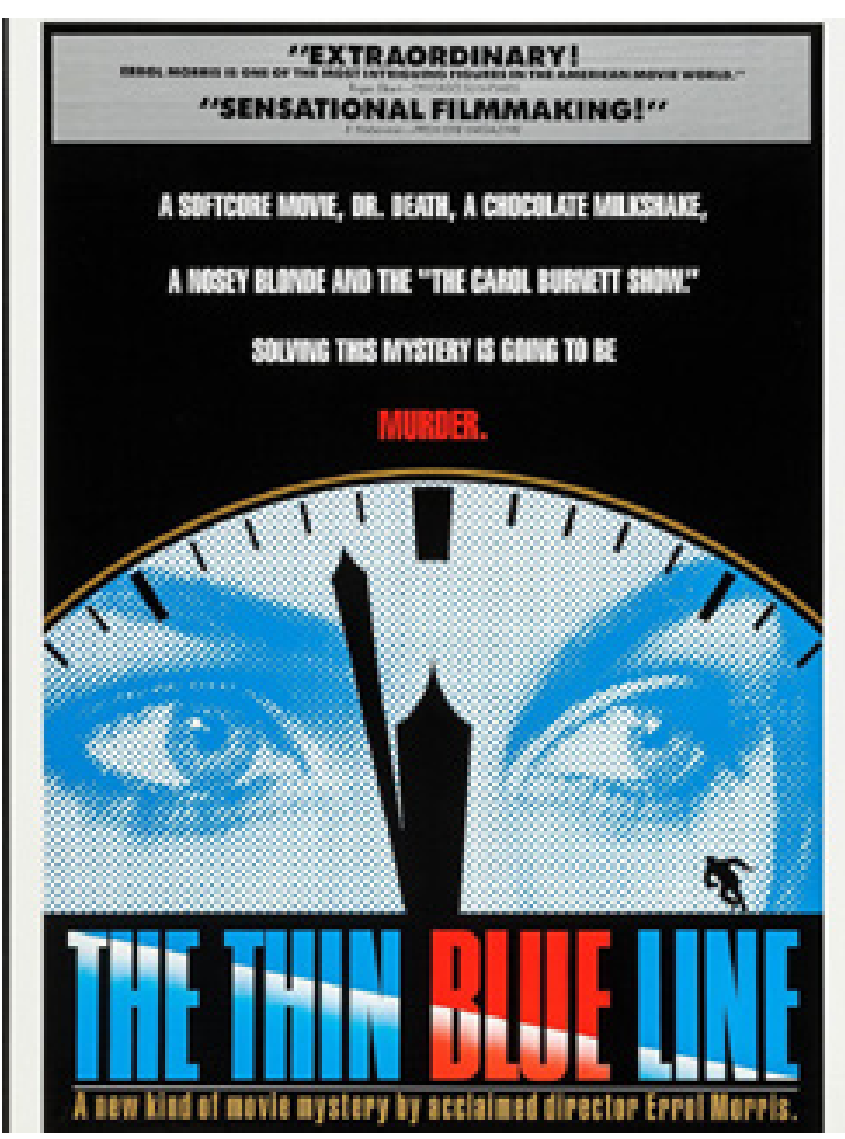

The Thin Blue Line (1988). En Film Affinity Perú. Recuperado de https://www. filmaffinity.com/pe/film412084.htmI

especializados en docudramas policiales como Investigación Discovery (ID, 1996), donde a las entrevistas y los archivos audiovisuales y fotográficos, se suma, en no pocos casos, la voz de un narrador que ofrece las "claves" de la investigación y el relato de los hechos.

Hoy la televisión por streaming ha vuelto a poner de moda los docudramas policiales seriados. En la web, asumen el formato de miniseries con finales abiertos, y no siempre felices, acudiendo a los códigos dramatúrgicos que le dieron origen y al uso de estructuras participativas que, en la mayoría de los casos, trasladan el protagonismo de la narración a las personas que vivieron los acontecimientos. Sin embargo, el docudrama no sólo se ha ocupado de crímenes y secuestros, la reconstrucción de eventos históricos, que carecen de referentes audiovisuales, es otro de los contenidos que sobresalen entre las propuestas que utilizan la ficción para recrear el pasado.

Aquí, los realizadores acuden una vez más a la entrevista como herramienta de autenticidad; sólo que en estos casos, los protagonistas y testigos son reemplazados por especialistas y estudiosos, cuyos conocimientos y análisis ofrecen los 
argumentos necesarios para otorgarle a la ficción la categoría de "documento".

Según Barroso (2009), en estos relatos históricos las escenas reconstruidas con actores reemplazan al uso de fotomontajes, grabados de la época, pinturas históricas, fotografías 0 filmaciones de actualidades, no sólo para solventar la falta de imágenes, sino sobretodo para añadir otros atractivos al discurso documental. Así conforman un espectáculo, donde se mezcla emoción con argumentación y entretenimiento con información.

Recientemente, la serie de la cadena Netflix Roman Empire (El Imperio Romano, 2019), marcó las diferencias con su antecesora Roma (2005) de la BBC, intercalando las escenas de ficción, con entrevistas a historiadores expertos en la Roma imperial. Como en otros docudramas, esta serie documental acudió a actores desconocidos; un rasgo que según Fuenzalida (2008) es habitual para producir un "efecto de realidad" en la audiencia. Para él, estos actores "no profesionales" resignifican el carácter no ficcional de la narración como “(...) una forma significante híbrida del carácter híbrido del género.” (p. 163).

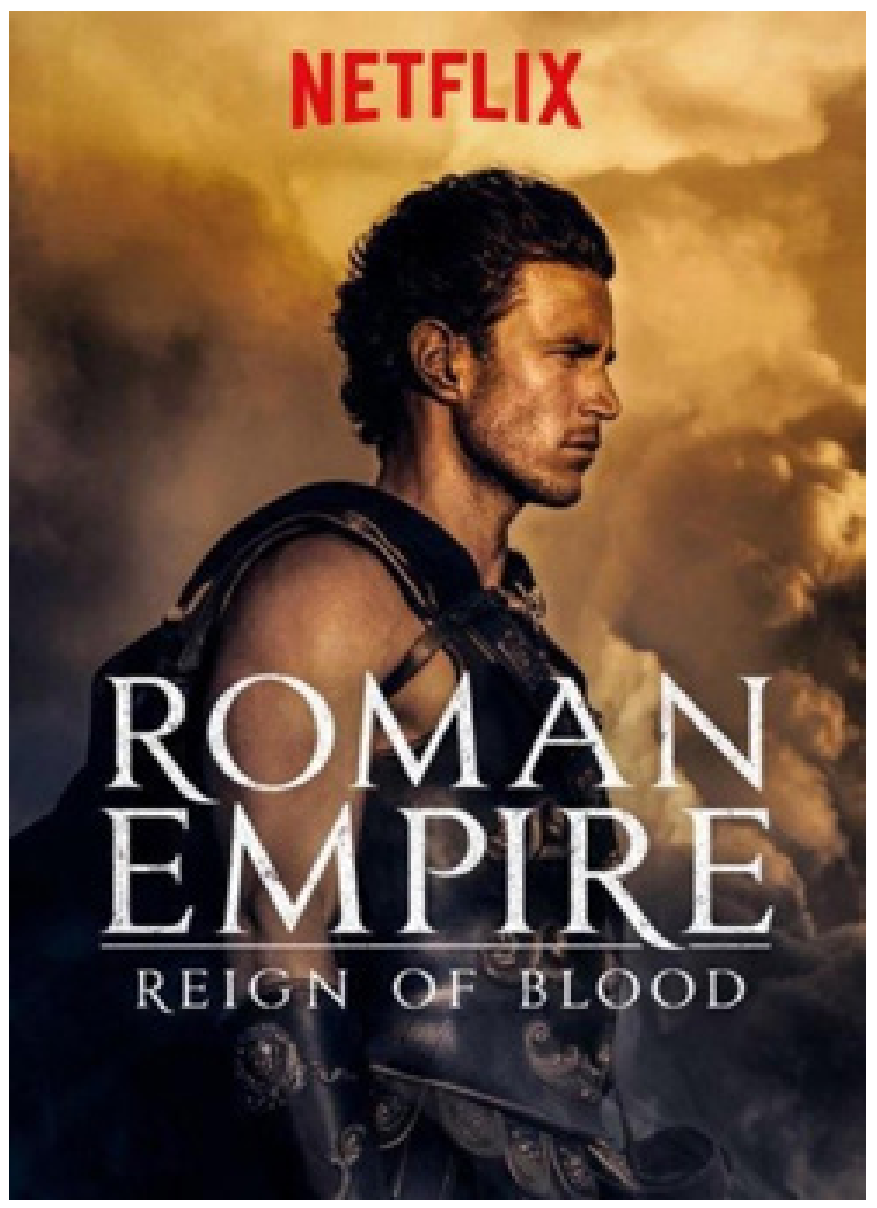

Roman Empire: Reign Of Blood (2016).En Option Paralysis. The Blog Of Ben Tobin Johnson. Recuperado de Https:// Bentobinjohnson. Files. Wordpress.Com/2017/08/Romanempire.Jpg?W=423\&H=593
El docudrama, de largo recorrido en el cine y la televisión, ya no es, sin embargo, la única expresión documental donde se diluyen las fronteras entre ficción y no ficción. El uso cada vez más extendido de la animación como técnica para representar realidades mucho más subjetivas, ha dado lugar a documentales animados, donde el recuerdo y las emociones "dibujadas" adquieren la categoría de "verdades", en palabras de las personas que las experimentan. Gracias a la animación, el documental puede por fin representar la esencia de un género que siempre buscó ir más allá de lo evidente.

\section{TRAZOS DE LA MEMORIA. LA PARADOJA DEL DOCUMENTAL ANIMADO.}

(...) el cine documental animado (...) resulta un ámbito en plena ebullición creativa que, desde las pocas obras que aún acumula, ya propone un auténtico desafío ontológico para el espectador. (...)

(Hachero Hernández, 2015, p. 123).

Si la imagen en el docudrama todavía se relaciona de alguna manera con el registro audiovisual, ¿que se puede decir de un dibujo?. La respuesta es: "mucho más". Los documentales que usan la animación para recrear realidades, a decir de Hachero Hernández (2015), nos proponen “(...) nuevas maneras de explorar la realidad desde el cine, de desafiar lo irrepresentable desde las posibilidades expresivas de la imagen animada (...)" (p. 123).

Eso que se consideraba "irrepresentable" es la memoria y la emoción; el mundo interno del realizador y de los personajes de la realidad, que ahora es posible traducir en imágenes. Así lo demostró Waltz with Bashir (Vals con Bashir, Israel, 2008), documental animado sobre la matanza de refugiados palestinos en el Líbano, premiado por el Círculo de Críticos de Nueva York como mejor película de animación y mejor documental, y referente usual de los estudiosos del género. Para su director, Aris Follman, la animación era el único lenguaje capaz de transmitir el universo interior del autor como protagonista $y$ de los personajes que en el film le ayudan a reconstruir una realidad: "(...) La única forma de hacer esta película era mediante la animación porque trata de la memoria perdida, de los sueños y del subconsciente." (Follman, en entrevista de Muñoz, 2009).

Aunque hoy está ligada a los avances de las tecnologías digitales, la animación es una antigua estrategia usada desde los inicios del cine para documentar una realidad imposible de registrar. El primer corto documental animado, The Sinking of the Lusitania (El Naufragio del Lusitania, 1915) del historietista Winsor McCay, recreó el ataque de un submarino alemán a un crucero Británico, que dio inicio a la intervención de Estados Unidos en la primera guerra mundial (Cock, 2008 y Gionco, 2015). El discurso de esta propuesta se acerca al estilo 
noticioso de la época, con intertítulos expositivos y fotografías que refuerzan la veracidad, intercalando animaciones que cobran una mayor fuerza emotiva cuando recrean el ataque, los intentos de supervivencia y el hundimiento final del barco.

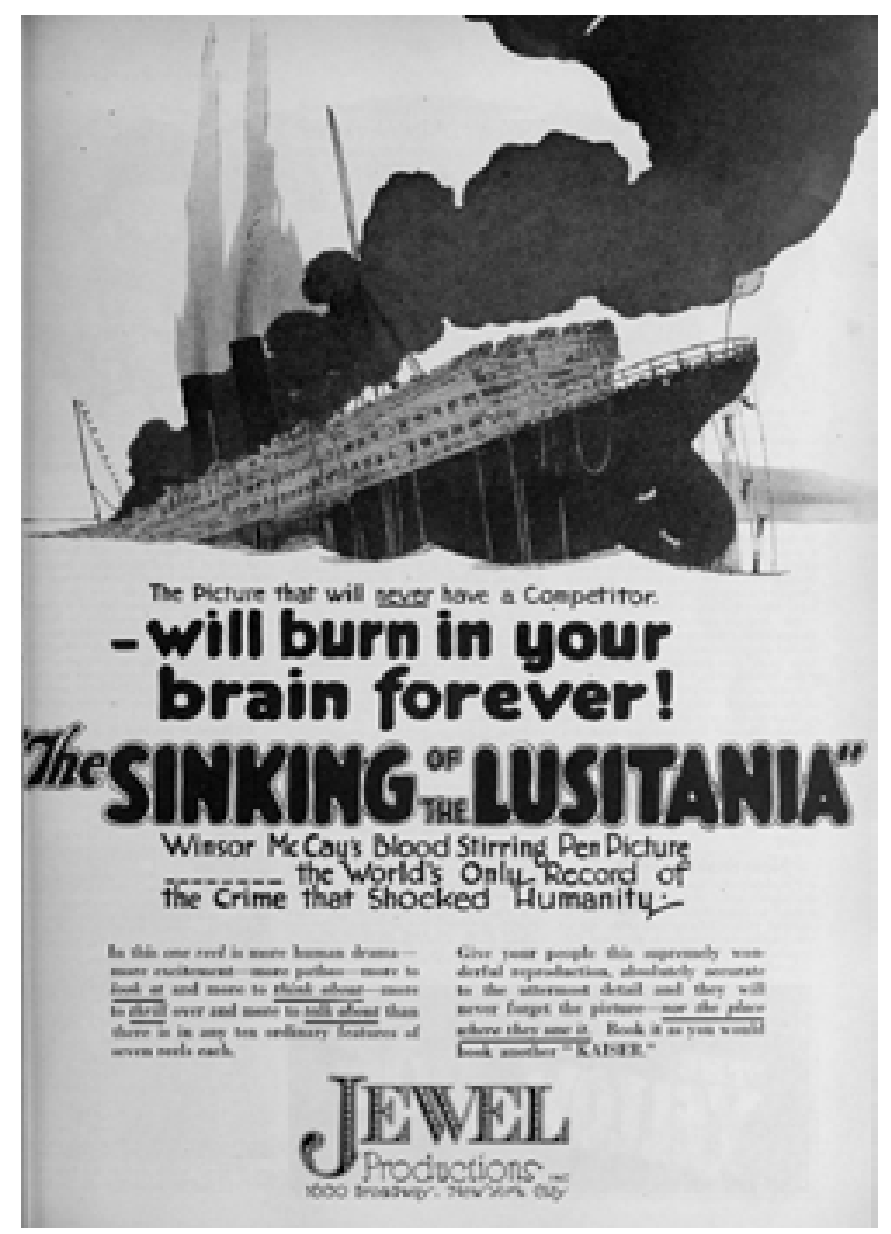

The Sinking of the 'Lusitania' (1918). En IMDb. Recuperado de https://www.imdb.com/title/tt0009620/mediaindex

Como en el caso del docudrama, los precursores del cine documental, Flaherty y Vertov, siguieron los pasos de McCay y usaron en los años veinte la animación; Flaherty, en el considerado el primer largometraje documental de la historia Nanook of the North (Nanuk El Esquimal", 1922), a través mapas animados, y Vertov, en la escena de la cámara que aparenta moverse sola en Man with a Camera (El Hombre de la Cámara, 1929). Entre esas fechas, también apareció el primer largometraje documental animado, Einstein's Theory of Relativity (La Teoría de la Relatividad de Einstein, Dave Fleischer, 1923), dando a luz una corriente educativa que subsiste hasta el día de hoy, donde la palabra del narrador y el conocimiento expresado en animación constituyen los únicos garantes de autenticidad.

Entre las nuevas tendencias del cine documental, denominado por Cock (2008) "post verité", en alusión al contraste con el "cine verdad", destaca el uso de la animación con diferentes objetivos en tres documentales premiados: "Bowling for
Columbine" (2002, Michael Moore) con la famosa secuencia de humor A brief history of the USA, creada por los realizadores de South Park con los personajes de la serie; Searching for Sugar Man (2012, Malik Bendjelloul) y la escena animada que presenta a la ciudad de Detroit, protagonista de uno de los plots de la historia del músico Sixto Rodríguez; y Life Animated (2016, Roger Ross Williams), que otorga un papel más testimonial y subjetivo a la animación, al representar los pensamientos de un personaje con autismo que encuentra, precisamente en los dibujos animados, una forma de comunicarse con el mundo y su entorno.

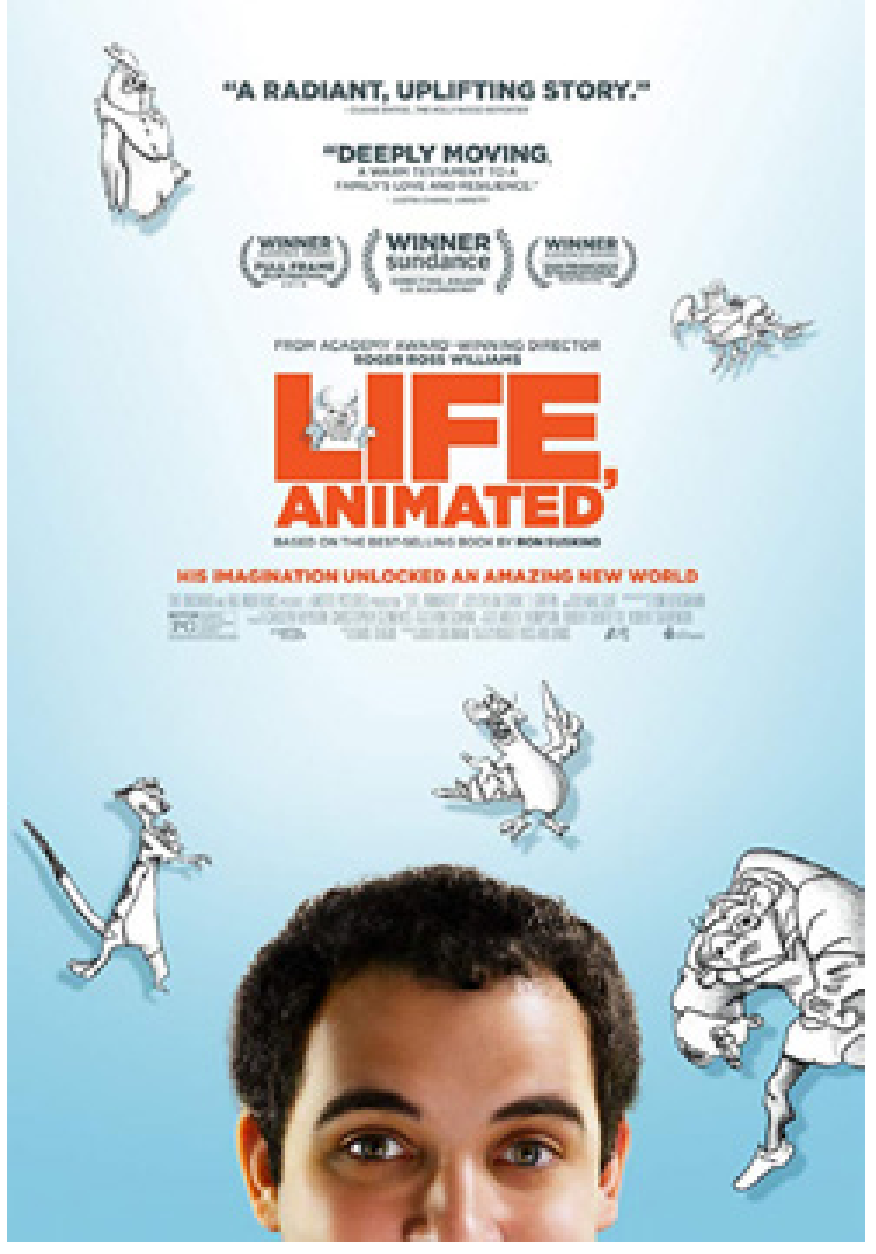

Life, Animated (2016). En IMDb. Recuperado de https://www. imdb.com/title/tt3917210/

Sin embargo, fue Aris Follman con Vals con Bashir (2008) quien estableció el verdadero regreso del género, recreando prácticamente todo el documental con animaciones que transitan por la memoria, las pesadillas y el trauma de su protagonista. Las imágenes de archivo, garantes de la existencia de la masacre de Sabra y Chatila que da origen al relato, ocupan la menor parte del film. Lo que Pinotti (2015) llama el "efecto documentalizante" de esa secuencia final fue explicado por el mismo Follman: "(...) esos 50 segundos de imágenes filmadas ponen el film entero en proporción. Ponen mi historia personal en proporción. Ponen la animación en proporción. Te muestran 
lo que realmente pasó." (Follman trad. en Hachero Hernández, 2015, p. 118).

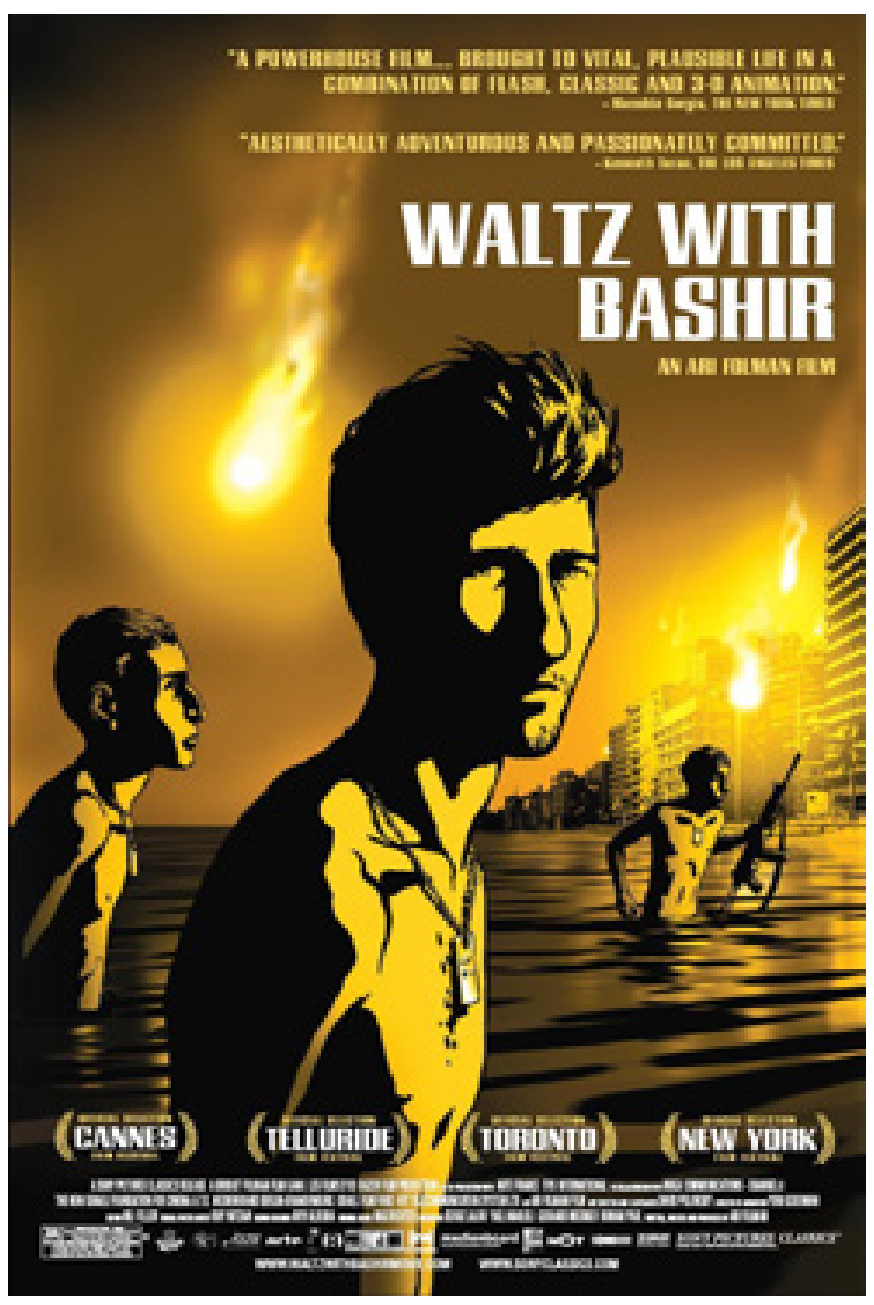

$\triangle$

Waltz with Bashir (2008). En IMDb. Recuperado de https:// www.imdb.com/title/tt1185616/

Tower (Torre, Keith Maitland, 2016), otro documental animado posterior a la obra de Follman, mostró un mayor equilibrio entre representación y simulación. El enfoque de esta propuesta no se centra, tanto en los aspectos internos de los personajes, sino en un acontecimiento compartido por ellos; el tiroteo masivo ocurrido en 1966 desde la torre de la Universidad de Texas, donde murieron 14 personas. En ese sentido, se acerca mucho más a la dramatización de un hecho, que a una visión personal como la de Vals con Bashir, y nos permite identificar una mayor variedad de recursos, incorporados con el fin de otorgarle autenticidad a la reconstrucción animada.

Como "docudrama" de animación, Tower reposa la veracidad de las imágenes dibujadas en la voz de protagonistas y testigos sobrevivientes de la masacre, cuyos distintos puntos de vista guían el relato estructurado al estilo de los documentales participativos. Pero también, utiliza la animación en el sentido de un falso documental, reproduciendo códigos visuales clásicos de los relatos de no ficción, como los encuadres de las entrevistas, que muestran a los implicados "dibujados" en el tiempo en que ocurren los hechos y con la voz de actores que interpretan sus declaraciones. La estructura misma es tratada como un relato informativo, que refuerza el realismo de los hechos contados mediante la animación.

La forma en que son narrados los eventos, también alimenta la construcción de una retórica de la facticidad, a través de lo que Plantinga denomina "símbolo"; el resultado de años de evolución del cine documental en los que se ha ido construyendo un "contrato inherente a este género", que lo ha catapultado a los ojos del espectador como una representación de veracidad (Plantinga, 2007, p. 52).

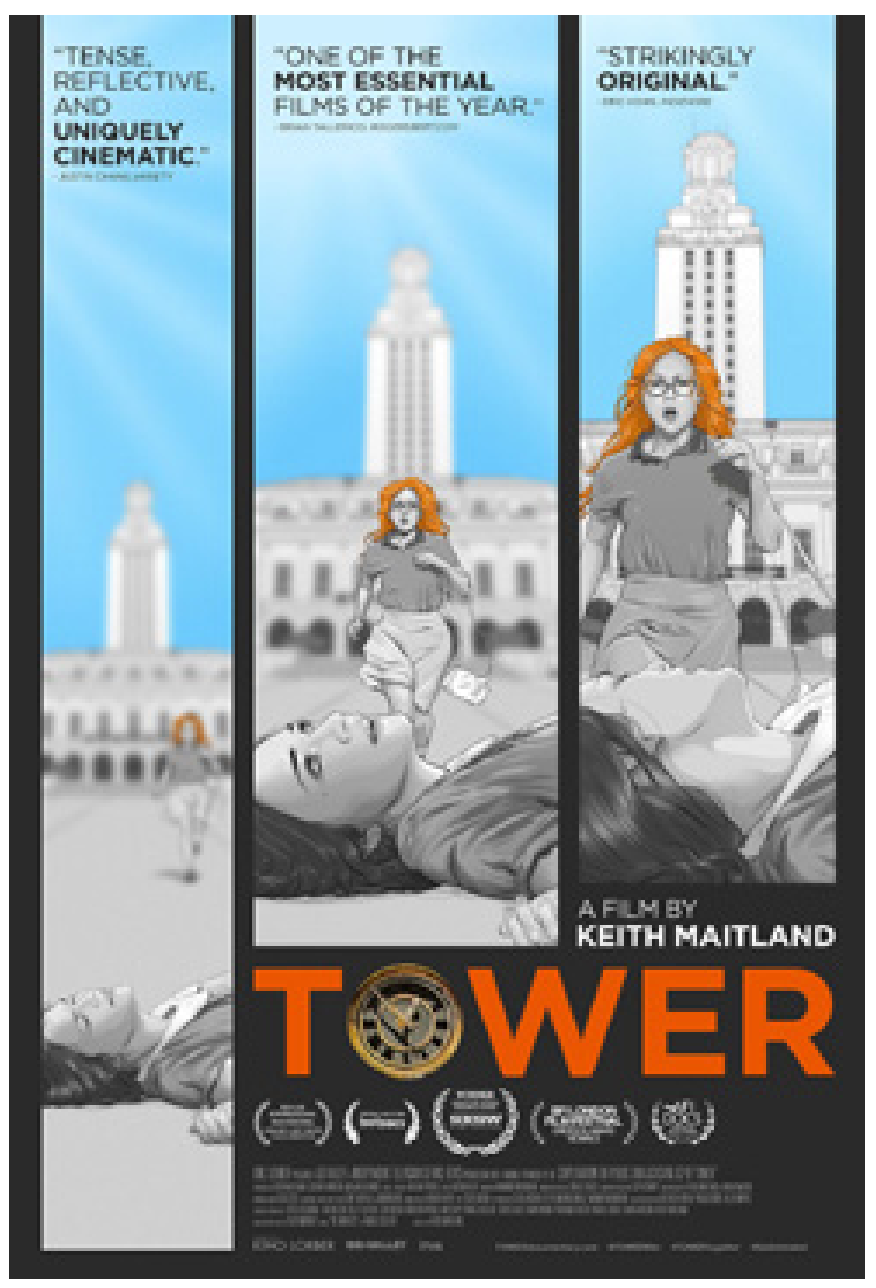

Tower (2016). En Kino Lorber. Experience Cinema. Recuperado de https://www.kinolorber.com/media_cache/ images/filmpageposter/Tower_poster_large.jpg

Estos códigos y estructuras propias de los relatos de no ficción, incorporan elementos dramatúrgicos de suspenso, que, en el caso de "Tower", recae en la intención de guardar la verdad de las declaraciones para el final. Recién transcurrida la mitad del documental nos van mostrando, poco a poco, a los referentes reales, para los que sí ha pasado el tiempo. En esta propuesta, como en otras que utilizan la reconstrucción ficcionada, el pasado no registrado queda destinado a la animación y el presente "registrable" a la representación y a la retórica. 
Los sucesos recreados también se encuentran con sus referentes reales a través del uso del archivo noticioso y del registro de época de los espacios donde sucedieron. Pero la mayor fuerza retórica del discurso se presenta en el tercer acto del documental, donde se unen los dos universos: la ficción animada y la representación de la actualidad. Los créditos finales evidencian la mediación mostrando a los personajes animados y a sus referentes reales, e indicando el nombre de los actores que los interpretaron.

En general, el lenguaje animado permite representar hechos del pasado que no pudieron ser registrados, procesos de larga duración 0 estados vinculados con la memoria, la emoción y el mundo interno de los personajes. Cualesquiera de estos contenidos adquieren facticidad en los documentales animados, a través de una narración realista y de la integración de las voces y/o imágenes que representan a sus referentes reales, como pruebas de veracidad. De esta manera, sin dejar su función documental, este relato de no ficción introduce el arte como forma de expresar una realidad y suma el entretenimiento, a la necesidad de estar informado.

\section{CONCLUSIONES}

Tanto el docudrama como el documental animado, parten de una investigación para recrear la realidad a través del uso de actores y otros componentes propios de la ficción, o de dibujos, que simulan a personas reales y los acontecimientos que protagonizan. La diferencia entre estas dos formas documentales de narrar se encuentra principalmente en el lenguaje mediante el cual son contados los hechos. En el docudrama, el "registro fotográfico fílmico" provee de mayor "autenticidad" al uso de la dramatización. Vemos y escuchamos a actores desconocidos en espacios reales, interpretando a los personajes que son parte de la realidad representada. En el documental animado, existe una mayor distancia entre la realidad y su reconstrucción. Ya no son personas, sino dibujos de sus acciones, de sus recuerdos, de sus emociones.

El aporte a nivel discursivo de la recreación, fílmica o animada, es su capacidad para representar ciertos eventos de la realidad externa 0 interna de las personas, difíciles de registrar a partir de los mecanismos de la no ficción. En el caso del docudrama, éstos suelen ser acontecimientos del pasado sin referentes audiovisuales. Por su parte, el documental animado se ha ocupado también de la reconstrucción de sucesos pero, a diferencia de la imagen fílmica, la animación permite también profundizar en aspectos internos de los personajes; el recuerdo, los sueños, los estados de ánimo, los sentimientos, las emociones.

Aunque la mediación del lenguaje otorga posibilidades diferentes a cada uno de estos relatos, ambos coinciden en la necesidad de establecer ciertos recursos discursivos que les confieran el carácter retórico propio de la representación documental. De los docudramas y documentales animados analizados en este estudio, se desprende que estos recursos retóricos son:

- El uso de declaraciones fragmentadas, obtenidas mayormente de entrevistas a personas que vivieron los acontecimientos, fueron testigos de ellos o los conocen porque los han estudiado o practicado como parte de su quehacer profesional.

- La utilización de periódicos, revistas, fotografías, ilustraciones, pinturas de época, audios y archivos audiovisuales noticiosos 0 de origen casero, que comprueban la existencia de los eventos narrados.

- El registro actual de espacios y objetos vinculados a los acontecimientos representados, que actúan como iconos de autenticidad de las historias del pasado.

- La representación fáctica del punto de vista del realizador, a través de la narración en primera persona 0 de la voz de un narrador, que se ofrecen como garantes de autenticidad y portadores de experiencias vividas o del conocimiento investigado.

- La incorporación de intertítulos que ofrecen información destacada y factual de los sucesos representados.

- El empleo de estilos "realistas" que provienen de escuelas documentalistas observacionales, participativas y catalizadoras, como el Cinema Verité, que se ofrecen como un símbolo discursivo de la veracidad de los contenidos narrados.

\section{FUENTES DE INFORMACIÓN}

Aristóteles. Retórica. (Traducido por Alberto Bernabé en 1998). Madrid: Alianza Editorial.

Barroso, J. (2009). Realización de documentales y reportajes: técnicas y estrategias del rodaje en campo. Madrid: Síntesis.

Barnouw, E. (1996). El documental, historia y estilo. Barcelona: Gedisa.

Cebrián Herreros, M. (2007) Información audiovisual. Concepto, técnica, expresión y aplicaciones. (Segunda ed.). Madrid: Síntesis.

Cock, A. (2008). Documental y animación: ¿realidad desdibujada? (Entrada de blog). Recuperado de http://alejandro. cock.googlepages.com/ELDOCUMENTALANIMAD0.doc

Flaherty, R. (1985). La función del documental. En Colombres, A. (comp.), Cine, antropología y colonialismo (pp. 57-60). Buenos Aires: Ediciones del Sol-FLACSO.

Fuenzalida, V. (2008). 0 docudrama televisivo. Matrizes, 2(1), 159-172. Recuperado de http://www.redalyc.org/articulo.oa?id=143012788008 
Gionco, P. (20 de abril de 2015). La animación en el cine documental. El Ángel Exterminador. Revista Digital de Cine, (19). Recuperado de http://elangelexterminador.com.ar/laanimacion-en-el-cine-documental/

Hachero Hernández, B. (2015). Deformar a la Gorgona: la imagen animada como estrategia para documentar el horror. Con A de Animación. (5), 114-125. doi:http://dx.doi. org/10.4995/caa.2015.3542. Recuperado de http://hdl.handle. net/10251/50703

Muñoz, J. M. (14 de Febrero de 2009). Entrevista a Ari Folman. El baile del horror. El País. Recuperado de https://elpais.com/ diario/2009/02/14/babelia/1234571952_850215.html

Nichols, B. (2011). La representación de la realidad: cuestiones y conceptos sobre el documental. Barcelona: Paidós.

Pinotti, L. (2015). La animación no ficcional. Un análisis sobre la construcción del sentido en el documental animado Vals con Bashir. Revista Cine Documental, (12). Recuperado de http:// revista.cinedocumental.com.ar/la-animacion-no-ficcional-unanalisis-sobre-la-construccion-del-sentido-en-el-documentalanimado-vals-con-bashir/

Plantinga, C. (2007). Caracterización y ética en el género documental. Archivos de la Filmoteca, 57, 46-67. Recuperado de http://www.archivosdelafilmoteca.com/index.php/archivos/ article/view/205

Poppy, N. (1 de abril de 2004). An Interview with Errol Morris. The Believer, (12) Recuperado de https://believermag.com/aninterview-with-errol-morris/

Raventós, C., Torregrosa, M. y Cuevas, E. (2012). El docudrama contemporáneo: rasgos configuradores. Trípodos, 1(29), 117132. Recuperado de http://www.tripodos.com/index.php/ Facultat_Comunicacio_Blanquerna/article/view/12/382

Tuchman, G. (1983). La producción de la noticia. Barcelona: Ediciones Gustavo Gili S.A.

\section{FUENTES DE INFORMACIÓN}

Bendjelloul, M. (Director).Schildt, P..,Chinn, S.yBendjelloul,M. (Productores). (2012). Searching for Sugar Man. (Película documental). Suecia-Reino Unido-Finlandia: Red Box Films, Passion Pictures, Canfield Pictures.

David, S., Kelly, T. W. y Scott, S. (Productores). López, R. V. (Director). (2016). Roman Empire. (Serie de televisión). Estados Unidos: Netflix.

Dunn Meurer, T. y Cosgrove, J. (Productores). Akhtar, K. Taulère, P., Torres, G., Rosenfeld, K. y Mathis, M. (Directores). (1987). Unsolved Mysteries. (Serie de televisión). Estados
Unidos: Cosgrove/Meurer Productions, Lifetime Television.

Follman, A. (Director). Lalou, S., Meixner, G., Nahlieli, Y.,Paul, R. y Follman, A., (Productores). (2008). Waltz with Bashir. (Película documental animada). Israël-Alemania-Francia: Bridgit Folman Film Gang, Les Films d'Ici, Razor Film Produktion.

Flaherty, R. (Director y Productor). (1922). Nanook of the North. (Película documental). Estados Unidos-Francia: Les Frères Revillon, Pathé Exchange.

Flaherty, R. y Korda, A. (Directores). Korda, A. (Productor). (1937). Elephant Boy. (Película documental). Reino Unido: London Film Productions.

Fleischer, D. (Director). (1923). Miles Fadiman, E. y Fleischer, M. (Productores). Einstein's Theory of Relativity. ((Película documental). Estados Unidos: Out of the Inkwell Films.

Larsen, R. E., De Rochemont, L. y De Rochemont R. (Productores). (1935). The March of Time. (Serie Cinematográfica). Estados Unidos: Time Inc.

Maitland, K. (Director). Gilbride, M., Thomson, S. y Maitland, K. (Productores). (2016). Tower. (Película documental animada). Estados Unidos: Killer Impact.

McCay, W. (Director). (1915). The Sinking of the Lusitania. (Película documental animada). Estados Unidos: Universal Film Manufacturing Company

Moore, M. (Director). Glynn, K., Czarneck, J. y Moore, M. (Productores). (2002). Bowling for Columbine. (Película documental). Estados Unidos-Canadá-Alemania: United Artists, Alliance Atlantis Communications, Salter Street Films International.

Morris, E. (Director). Lipson, M. (Productor). (1988). The Thin Blue Line. (Película documental). Estados Unidos-Reino Unido: American Playhouse, Channel 4 Television Corporation, Third Floor Productions.

Ross Williams, R. (Director). (2016). Goldman, J. y Ross Williams, R. (Productores). Life Animated. (Película documental). Estados Unidos: A\&E IndieFilms, Motto Pictures, Roger Ross Williams Productions.

Vertov, D. (Director y Productor). (1929). Man with a Movie Camera. (Película documental). Unión Soviética: All-Ukrainian Photo Cinema Administration, VUFKU.

Vigo, J. y Kaufman, B. (Directores). Vigo, J. (Productor). (1930). À propos de Nice. (Película documental). Francia: Pathé-Natan. 